\title{
Kvinner med innvandrerbakgrunn og deres møte med helsearbeidere
}

\author{
Oddhild Bergsli og Ellen Beate Hellne-Halvorsen \\ OsloMet - storbyunderversitetet
}

\begin{abstract}
Abstrakt
Denne artikkelen tematiserer hvordan kvinner med innvandrerbakgrunn erfarer møte med helsepersonell i helsesektoren. Studien tar utgangspunkt i intervju med førstegenerasjons kvinner fra Pakistan diagnostisert med diabetes type 2 og de utfordringer de har for å gjøre livsstilsendringer. Studien retter oppmerksomheten mot kommunikasjonen mellom helsepersonell og kvinner med innvandrerbakgrunn. Kunnskap om helse og livsstil, flerkulturalitet og kultur-sensitiv kommunikasjon utgjør det teoretiske fundamentet for studien.

Det ble gjennomført syv kvalitative intervjuer, og resultatene viser at kvinner med innvandrerbakgrunn erfarer at de ikke får kulturtilpasset opplæring i kosthold- og fysisk aktivitet, to avgjørende determinanter for god og vellykket behandling av livsstilsykdommer. Videre viser resultatene at kvinnene led av angst og depresjoner som de ikke snakket med helsepersonell om. Dette ble et hinder for å gjøre livsstilsendringer. Kvinnene selv mente de manglet kunnskap som kunne gjøre deres fysiske og psykiske helse bedre. I kommunikasjonen mellom kvinnene og helsepersonell våget de heller ikke å stille spørsmål om sykdommen og sykdomsutviklingen. Videre opplevde de at helsepersonell hadde liten forståelse for deres kulturforankring.
\end{abstract}

Emneord: Innvandrerkvinner, kultursensitiv kommunikasjon, flerkulturell kompetanse, helseatferdsendring 


\section{Innledning}

I løpet av de siste 40 årene er Norge blitt et mer mangfoldig samfunn, både etnisk, religiøst, kulturelt og språklig (Kale, 2006, s. 9; Kunnskapsdepartementet, 2015, s. 21). Vi vil få en voksende eldre befolkning generelt og en stor gruppe aldrende innvandrerbefolkning (Statistisk sentralbyrå (SSB), 2016; Helse- og omsorgsdepartementet, 2013b, s. 11, 21 og 41; Kumar, Oppedal, Bystad, Dalgard \&Vangen, 2010, s. 56) som vil være med på å prege ulike helsearbeideres utdanning og deres yrkesutøvelse i eldreomsorgen.

Denne artikkelen vil utforske flerkulturell kompetanse og kultursensitivitet slik det kommer til uttrykk gjennom erfaringer og opplevelser til kvinner med innvandrerbakgrunn i deres møte med helsesektoren. Fra myndighetenes side skal helse- og omsorgstjenester være likeverdig for hele befolkningen (Helse- og omsorgsdepartementet, 2013a, s. 5).

Utdanning av helsepersonell, som helsefagarbeidere, sykepleiere og leger, underlegges visse føringer knyttet til mangfold og flerkulturell forståelse. I læreplanverket for grunnopplæringen, som også omfatter helsearbeiderfagutdanningen, betegnet som Fagfornyelsen, 2020, heter det blant annet: «En felles ramme gir og skal gi rom for mangfold, og elevene skal få innsikt i hvordan vi lever sammen med ulike perspektiver, holdninger og livsanskuelser» (Utdanningsdirektoratet, 2020). På universitet og høgskoler er de samme grunnideene videreført og implementert i opplæringen. I rammeplan for sykepleieutdanning heter det blant annet:

Det kulturelle mangfoldet er en realitet i alle samfunnssektorer. Denne utviklingen er spesielt synlig i storbyen og dens nærområder, som har en etnisk og kulturelt sammensatt befolkning. Studiet har derfor som mål å utdanne sykepleiere som er i stand til å møte dette mangfoldet og yte helsehjelp i samsvar med pasientenes kulturelle og språklige bakgrunn (Programplan for bachelorstudium i sykepleie, OsloMet, 2019).

Vi ser altså at intensjonen med opplæringen av helsepersonell inkluderer flerkulturalitet og mangfold. Denne studien retter søkelyset på brukeraspektet, på hvordan kvinner med innvandrerbakgrunn erfarer sitt møte med helsepersonell, med sin kultur og forståelse av sykdom og helse.

\section{Studiens formål og forskningsspørsmål}

Målet med denne studien er å få innsikt i opplevelser og erfaringer eldre kvinner med innvandrerbakgrunn fra Pakistan har i møte med helsepersonell. Disse kvinnene er diagnostisert med diabetes type 2, en livsstilssykdom som krever ulike tiltak for bedre helse. Perspektivet ligger på kommunikasjon knyttet til sykdomsutfordringer og livsstilsendringer. Problemstillingen for studien er som følger:

Hvordan opplever kvinner med innvandrerbakgrunn kommunikasjon om egen helse med profesjonelle helsearbeidere? 
Dette har ledet oss til følgende forskningsspørsmål:

1. Hvilke utfordringer mener kvinner med innvandrerbakgrunn de har i møte med helsearbeidere?

2. Hva slags flerkulturell kompetanse synes nødvendig for helsearbeidere på bakgrunn av disse kvinnenes livshistorier?

Studien baseres på en sosiokulturell tilnærming som generelt studerer interaksjon mellom individ og samfunn, mellom individ og sosiokulturelle omgivelser (Säljö, 2001, s. 131-159). Dette innebærer at kvinnenes erfaringer og opplevelser med en livsstilssykdom og deres møte med helsepersonell sees i lys av deres sosiale kontekster og kulturbakgrunn. Videre søker vår unders $\emptyset \mathrm{k}-$ else å utlede mer konkret hva slags innhold begrepet «flerkulturell kompetanse» bør ha i interaksjonen mellom profesjonelle helsearbeidere og kvinner med innvandrerbakgrunn.

Den teoretiske inngangen knytter seg til tre hovedområder innenfor en flerkulturell interaksjon og helsekommunikasjon. Den første dreier seg om sammenhengen mellom fysisk og psykisk helse, og hvordan fysisk og psykisk helse kan være med på å $\varnothing$ ke livsmestring, livsglede og velvære (Antonovsky, 1987). Den andre har særlig perspektiv på kommunikasjon med blikk på flerkulturell og kultursensitiv kommunikasjon (Dahl, 2017; Vike \& Eide, 2009; Sletteland, 2014). En tredje teoretisk inngang betegner vi som helsepedagogikk, et begrep som i denne sammenheng handler om sykdomsforløp og hvordan kommunisere utfordringer og behandling av sykdom (Prochaska \& DiClemente, 1983).

\section{Forskning på feltet}

For å plassere denne studien innenfor et større forskningsfelt, søkte vi studier som omhandler tematikker som flerkulturalitet og kvinner; kvinner med innvandrerbakgrunn og helse; kvinner med innvandrerbakgrunn og kommunikasjon, helsearbeidere og flerkulturell kompetanse. Strategiske litteraturs $\varnothing \mathrm{k}$ ble gjort gjennom søkemotorer som ERIC, Education Source, Cinahl og Academic Search Ultimate. Av 68 artikler innenfor feltet, dreide de fleste seg om spesifikke sykdommer som kreft, fødsler eller bruk av teknologiske hjelpemidler ved sykdom. Vi sto igjen med sju studier som på ulike måter tangerer denne studiens tematikk, og som vi vil redegjøre nærmere for i dette kapitlet.

Undersøkelsene berører temaer som kommunikasjon, kulturelt tilpasset omsorg og utvikling av flerkulturell kompetanse hos helsepersonell. Kommunikasjonsproblemer mellom helsepersonell og pasienter er et kjent fenomen på grunn av språk- og kulturforskjeller. En finsk studie undersøker utfordringer i kommunikasjon mellom finske helsearbeider og voksne somaliere. Den retter særlig oppmerksomheten mot måter å kommunisere på, og konkluderer blant annet med at finner er mer fåmælte og tilbaketrukne enn somaliere, som er mer åpne og direkte. Dette kan være med på å påvirke kommunikasjonens innhold og samforståelse (Degni, Suominen, Essén, El Ansari \& Vehviläinen-Julkunen, 2012, s. 330-343).

En annen finsk studie tematiserer viktigheten av å utvikle flerkulturell kompetanse hos helsearbeidere. Unders $\emptyset$ kelsen viser at $\varnothing \mathrm{kt}$ kompetanse i flerkulturalitet ga helsepersonell også mer bevissthet om egne kulturelle trekk, måter å tenke på, vurdering av egen kommunikasjonspraksis og anerkjennelse av pasienters forskjellige kulturelle trekk (Kaihlanen, Hietapakka, \& Heponiemi, 
2019). Noe av det samme viser studien om australske helsefagstudenter som fikk opplæring i kulturelle ulikheter med utgangspunkt $i$ aboriginenes kultur. Målet var å bli mer bevisste og utfordre egne verdier, tro og stereotypier, og vurdere ulike kommunikasjonsbarrierer som forstyrrer utviklingen av tillit til de aboriginske pasientene (Kline, Godolphin, Chhina \& Towle, 2013 s. 5-17).

Flere studier har lignende konklusjoner om at opplæring i egne og andres kulturelle koder er avgjørende for god omsorg og helseforståelse. En sveitsisk undersøkelse slår fast at helsearbeidere må kontinuerlig utvikle og reflektere over sin interkulturelle kommunikasjon (Ikhilor et al., 2019, s. 2200-2210). Parthab Taylor, Nicolle \& Maguire, (2013) gjennomførte intervjuer med helsepersonell for å identifisere ulike barrierer som hindret god helsehjelp til voksne minoriteter, både kvinner og menn, som snakket dårlig engelsk. De fant ut at lav health litracy, altså svak helseforståelse, hindret minoritetene i å motta helsehjelp (Parthab Taylor, Nicolle \& Maguire, 2013, s. 35-43). Tilsvarende viser en italiensk studie behov for at helsepersonell bør få kontinuerlig opplæring i kulturelt tilpasset omsorg (Cicolini, et al. 2015, s. 536-543). Den er særlig rettet mot sykepleiere som må forberedes på økende mangfold i pasientpopulasjonen og endrede helseforespørsler i lys av at kulturell kompetent omsorg gir mer tilfredshet og bedring av helsetilstand generelt.

Møte mellom innvandrere og helsepersonell krever i noen tilfeller bruk av tolk. I en norsk studie ble det fokusert på samarbeidet mellom helsepersonell og tolker, hvor tolkene har en sentral plass i kommunikasjon mellom helsepersonell og pasienter. Konklusjonen her er at også tolker bør være kvalifiserte kulturformidlere med flerkulturell kompetanse (Hanssen \& Alpers, 2010).

Ingen av disse omtalte studiene retter søkelyset mot eldre kvinner med innvandrerbakgrunn og deres møte med helsepersonell. Vi har heller ikke funnet studier som bare tar for seg erfaringer til innvandrerkvinner som har en livsstilssykdom med sammensatte utfordringer. Denne studien er derfor et bidrag til større innsikt i denne tematikken.

\section{Teoretisk forankring}

I dette kapitlet redegjøres det for ulike teoretiske innganger til vår studie av kvinner med innvandrerbakgrunn og deres møte med helsepersonell. Teorigrunnlaget relaterer seg til innholdskomponenter som vi mener er sentrale i kommunikasjon mellom innvandrerkvinner med livsstilssykdom og helsepersonell. Den teoretiske forankringen grupperer vi innenfor tre temaområder: Sammenhengen mellom fysisk og psykisk helse, interkulturell og kultursensitiv kommunikasjon og helsepedagogikk. Kapitlet innledes først med begrepsavklaringer.

\section{Begrepsavklaringer}

Et overordnet begrep i studien er flerkulturalitet og flerkulturell kompetanse. Flerkulturalitet reflekterer en beskrivende kulturforståelse, der ulike grupper representerer ulike kulturer innenfor et samfunn (Dahl, 2017, s. 46). Disse begrepene krever også en nærmere forklaring av begrepet kultur. 
Kultur kommer fra latin og betyr å «dyrke» (colere). Kultur handler blant annet om normer, spilleregler og samhandlinger innenfor en gruppe og mellom grupper og mennesker, som igjen er forankret i verdier, måter å kommunisere og handle på. Tilhørighet til en kultur gir gjenkjennelse og stabilitet, og kan markere grenseoppgang til andre kulturer (Horntvedt, 2015, s. 40-41). Ifølge Eriksen er kultur det lærte, det kognitive og symbolske aspektet ved tilværelsen (Eriksen, 2010, s. 15). Vi vil utdype kulturbegrepet nærmere i forbindelse med interkulturell kommunikasjon og kultursensitivitet

Flerkulturell kompetanse indikerer kompetanse i flerkulturalitet, der kompetansebegrepet viser til kunnskaper, holdninger og ferdigheter, samt evne til å anvende denne kompetansen i kjente og ukjente sammenhenger og situasjoner, løse oppgaver og mestre utfordringer. Videre innebærer kompetanse evne og forståelse til refleksjon og kritisk tenkning (Utdanningsdirektoratet, u.å.). Å inneha flerkulturell kompetanse indikerer et bredt spekter av kompetanser innenfor det flerkulturelle feltet.

Et annet sentralt begrep i studien er innvandrer. Innvandrere er definert som personer som selv har innvandret til Norge, og som er født i utlandet av utenlandsfødte foreldre og/eller av fire utenlandsfødte besteforeldre (SSB, 2019). I dag snakker vi om innvandrere og etterkommere som er født i Norge.

\section{Sammenhengen mellom fysisk og psykisk helse}

Antonovskys begrep om salutogenese dreier seg om en helhetlig forståelse av sykdom, der sammenhengen mellom psykiske og fysiske helse er avgjørende for å forstå og mestre sin sykdom (Antonovsky, 1987, s. 1-14). Fysisk og psykisk helse er ifølge Antonovsky, to determinanter som er viktige for å utvikle god helse. Den tradisjonelle oppfatning av helse er motsatt av salutogenese, altså patogenese, som omhandler risikofaktorer og hva som er årsaken(e) til at sykdom oppstår.

Salutogenesisk tenking er å få kunnskap og erfaringer om hele personen, ikke bare fokusere på sykdommen isolert. Den totale livssituasjonen må vurderes for å forstå helsetilstanden og sykdomsopplevelsen hver og en har, betegnet som Sence of Coherence (SOC) (Antonovsky, 1987, s. 3-5). En salutogenesisk forståelse av sykdom gir ingen garanti for å løse de komplekse problemene, men kan skape en dypere kunnskap og forståelse om helsen for hver enkelt person. Dette krever evne til å bruke egne ressurser, og som må læres og dermed være i fokus ved behandling av sykdom (Antonovsky, 1987, s. 15). En sterk SOC er avgjørende for håndtering av stressfaktorer som har innvirkning på helsen (Antonovsky, 1987, s. 164). For å bevege seg i en helsefremmende retning må en få forståelse for sin psykiske og fysiske helse. En antar at de fleste har et indre ønske om å oppnå mestring av egen helse og helseproblemer. SOC bygger på om vi opplever tilværelsen som begripelig, håndterbar og meningsfylt (Antonovsky, 1987, s. 16-17), at en ved sykdom kan tilegne seg, bearbeide og forstå grunnleggende helseinformasjon som blir gitt (Kumar \& Magnus, 2017, s. 152). For å oppnå et positivt resultat må en oppleve at egen helsesituasjon er påvirkelig, forklarende og at utfordringene er overkommelige.

Antonovsky mener at personene selv må være styrende i sin sykdomsbehandling, ved å forstå hvordan en kan påvirke og få overkommelige utfordringene for bedret helseoppnåelse (Antonovsky, 1987, s. 14-32). Ved helsekommunikasjonen bør en derfor ta tak i både den fysiske og psykiske 
helsen, ifølge Antonovskys teori. Vi mener dette perspektivet er særlig relevant i møte mellom helsepersonell og kvinner med en annen kulturell bakgrunn når helse- og livsstilsforståelse kommuniseres.

\section{Helsekommunikasjon: Interkulturell og kultursensitiv kommunikasjon}

Kommunikasjon dreier seg om å forstå og produsere verbalspråklige ytringer og ikke-verbale tegn eller signaler som passer inn i sammenhengen og er hensiktsmessig i kommunikasjonssituasjonen (Eide \& Eide, 2018, s. 17). Helsekommunikasjon handler om hvordan helse kommuniseres, og er ofte enveis og asymmetrisk, som for eksempel ved statlig helseinformasjon eller kommunikasjon mellom pasient og helsepersonell. En forutsetning for at kommunikasjonen blir forstått, er at den åpner for gjensidige tilbakemeldinger og tolkninger. Informasjon, råd og veiledning er en av de viktigste oppgavene helsepersonell har (Sletteland, 2014, s. 26-27).

\section{Symmetri og asymmetri i kommunikasjon}

Asymmetri i helsekommunikasjonen kan utfordre relasjonen mellom helsearbeider og pasient. Jensen og Ulleberg sier at «det kan være krevende og komplisert å vise tillit til profesjonsutøvere når man som bruker er i en posisjon som er preget av både avmakt og manglende kunnskap» (Jensen \& Ulleberg, 2019, s. 185). Helsepersonell har faglige kunnskaper og fagspråk som kan være med å skape både tillit og avmakt eller hjelpeløshet hos pasienten (Jensen \& Ulleberg, 2019, s. 186). Enhver omsorgssituasjon, sier Dahl, vil innebære et asymmetrisk forhold, hvor vi har en hjelper og en som mottar hjelp (Dahl, 2017, s. 77).

\section{Interkulturell kommunikasjon}

Dahl definerer interkulturell kommunikasjon som kommunikasjon mellom aktører med ulik kulturell bakgrunn (Dahl, 2017, s. 77). Å oppnå gjensidig forståelse kan være en utfordring i møte med ukjente og nye kulturer. «Kultur dreier seg om systemer av kunnskap, verdier og betydninger mennesker bruker for å orientere seg i verden» (Vike \& Eide, 2009, s. 15). En kultur er derfor ikke statisk, men vil endre seg over tid med samfunnsutvikling og politiske forhold. Benedicte Ingstad sier at kultur kan bidra til å forme sykdom fordi kultur kan knyttes til forståelse av sykdom, opplevelse av symptomer og legitimasjon av sykdom. Å forstå eller tolke kroppslige symptomer er basert på kulturell kunnskap, erfaringer og reaksjoner (Ingstad, 2015, s. 37 og 40). På denne måten kan møte mellom helsepersonell og pasienter utfordre kunnskapen til egen og andre kulturers holdning til sykdom og behandling av sykdom, og hvordan dette gjensidig kommuniseres.

Kulturer kan være tuftet på kollektivistisk eller individualistisk tankegang. Kjennetegn på kollektivistiske kulturer og samfunn er at hensynet til fellesskapet settes foran egne behov (Jensen \& Ulleberg, 2019, s. 245-246). Norge og andre vestlige samfunn regnes for å være individualistisk orienterte samfunn. For helsearbeidere og pasienter kan dette bli et møte mellom kollektivistisk og individualistisk kulturforståelse. 


\section{Kultursensitivitet}

Kultursensitivitet handler om å være følsom eller sensitiv overfor mennesker fra en annen kultur med hensyn til tradisjoner og atferd (Jensen \& Ulleberg, 2019, s. 265). Denne følsomheten eller forståelsen kan oppøves og gjøres bevisst. I engelsk terminologi omtaltes kultursensitivitet som «Diversity, Awarness, Encounter, Knowlegde, Consideration, Understanding, Respect and Tailoring», (Foronda, 2008, s. 210). Det handler om å ta hensyn til, vise respekt og akseptere andre kulturer og væremåter. Dette er vesentlige elementer i helsekommunikasjon og ikke minst å tilpasse kommunikasjonen til den enkelte pasient ut fra deres kulturelle bakgrunn og tilhørighet.

\section{Helsepedagogikk: Den transteoretiske modellen}

Kunnskap om helsekommunikasjon og kultursensitivitet kan bidra til endringsprosesser i behandling av sykdom og dermed bli mer målrettet. Når behandling av sykdom innebærer endringer av atferd, kan det være hensiktsmessig å benytte modeller for atferdsendring. Det finnes ulike modeller brukt $\mathrm{i}$ atferdsendringsprosesser, og vi har i denne studien valgt ta utgangspunkt $\mathrm{i}$ denne transteoretiske modellen, også kalt stadiemodellen, utviklet av Prochaska og DiClemente (1983). Begrunnelse for valg av den transteoretiske modellen er at den ikke er lineær, men kan ta utgangspunkt i der hver pasient befinner seg i sin tenking. På denne måten kan modellen fungere som helsepedagogisk hjelp.

Den transteoretiske modellen er delt inn i følgende fem stadier: Før-overveielse-, overveielse-, forberedelse-, aktivitet- eller handlings- og opprettholdelsesstadiet (Prochaska \& DiClemente, 1983).

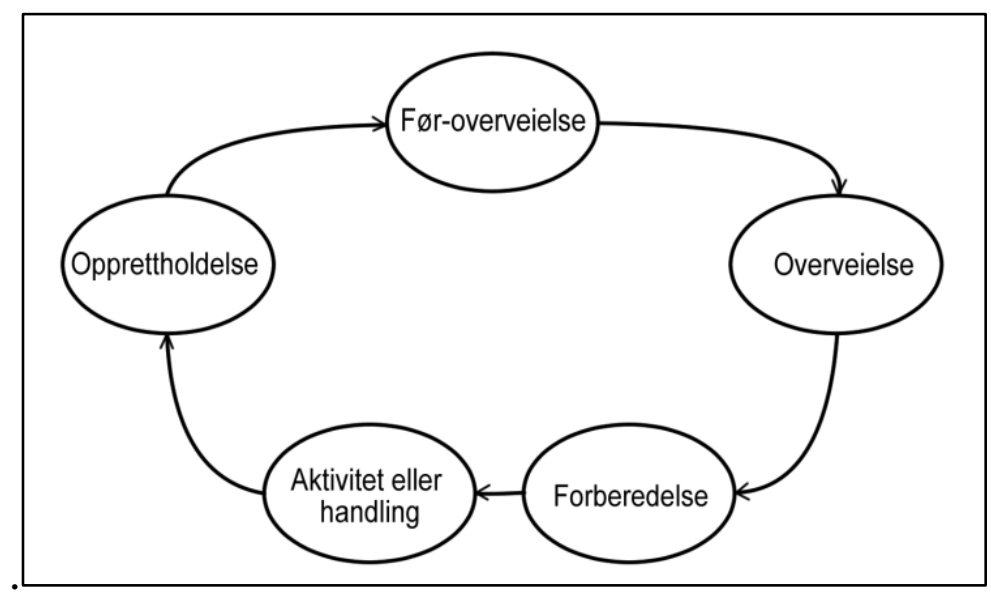

Fig 1. Her vises de fem stadiene i den transteoretiske modellen (Prochaska \& Di Clemente, 1983)

Den som skal motivere til atferdsendring i kosthold og fysisk aktivitet, bør ha kunnskap om hvilket stadium personen eller pasienten befinner seg på. Sannsynligvis er det store individuelle forskjeller i kunnskap, motivasjon og utholdenhet i å forandre livsstilen. En helseatferdsendring er en prosess som bør foregå gradvis og med tett oppfølging for å holde motivasjon oppe. 
De fleste vil gå frem og tilbake mellom stadiene. På de første stadiene er det vanskelig å tenke hva og hvordan endringene skal være fordi kunnskap om helseatferdsendring kan mangle. Hvis en mislykkes flere ganger, kan en tilslutt miste motivasjonen. I overveielsesstadiet finnes mange «kroniske overveiere», de som ikke kommer seg videre (Wester, Wahlgren, Wedman \& Ommundsen, 2008, s. 89). «De kroniske overveierne» venter ofte på en gylden anledning til å starte med livsstilsendringene. I det tredje stadiet har personen bestemt seg for å endre atferd. Men negative erfaringer kan hindre personen i å utføre endringene, derfor er motivasjonen viktig. Når hindringene er tilbakelagt, vil aktiv innsats holde motivasjonen oppe (Prochaska \& Di Clemente, 1983). Siste stadiet har fokus på opprettholdelse, hvor varige endringer hindrer tilbakefall.

\section{Metode}

Studiens overordnede mål er å få innsikt i opplevelser og erfaringer som eldre kvinner med innvandrerbakgrunn har i møte med helsepersonell. Perspektivet ligger på helsekommunikasjon mellom kvinnene og de profesjonelle helsearbeidere, slik kvinnene erfarte kommunikasjonen. Gjennom semi-strukturerte intervju åpnes det for kunnskaper om menneskers livssituasjoner, meninger, holdninger og opplevelser. Å benytte intervju som metode gir et innblikk i informantenes livsverden fra deres eget ståsted (Brinkmann \& Tanggard, 2010, s. 19). Vi vil først gi en beskrivelse av det studerte feltet.

\section{Feltbeskrivelse}

Forskning viser at med $\varnothing$ kende alder generelt, vil flere få livsstilsykdommer som diabetes type 2 (Kumar et.al. 2010, s. 58; Thran et al., 2010). Arbeidsinnvandrere, som kom til Norge på 1970tallet, er i dag gjennomsnittlig over 60 år. HUBRO-undersøkelsen (Helseunders $\varnothing$ kelsen i Oslo) viser at $90 \%$ av kvinnelige pakistanske innvandrere har forhøyet risiko for diabetes type 2, og at debutalderen for sykdommen er lavere hos denne gruppen enn befolkningen for $\emptyset$ vrig. (Glenday, Kumar, Tverdal \& Meyer, 2006, s. 350-351; Wium, Gulseth, Eriksen \& Birkeland, 2013; Hjellset, Bjørge, Eriksen \& Høstmark, 2011). Helsearbeidere vil i fremtiden komme i kontakt med innvandrere diagnostisert med livsstilsykdommer. Dette vil kreve kunnskap om flerkulturalitet og flerkulturell forståelse for å kunne gi best mulig helsehjelp.

Studien retter oppmerksomheten mot førstegenerasjons kvinner med innvandrerbakgrunn, alle diagnostisert med diabetes type 2. Sykdomsbildet i seg selv er ikke et primært perspektiv i studien, men fungerer som et eksempel på en livsstilsykdom som kan implisere flere utfordringer for pasientene selv og for deres møte med helsepersonell. Kvinnene er henvist av fastlegen til en kommunal frisklivssentral. Helsedirektoratets definisjon av frisklivssentral er følgende: «Frisklivssentralen er en helsefremmende og forebyggende kommunal helsetjeneste. Målgruppen er de som har $\varnothing$ kt risiko for, eller som har utviklet sykdom og trenger støtte til å endre levevaner og mestre helseutfordringer» (Helsedirektoratet. u.å). Frisklivssentralen jobber med helsefremmende og forebyggende arbeid, og tilbyr kurs i kosthold og fysisk aktivitet. Frisklivssentralen vi besøkte er ledet av helsesøster og fysioterapeut som jobber spesielt aktivt med innvandrere. 


\section{Kvalitativt intervju}

Et kvalitativt intervju er en planlagt faglig samtale, hvor målet er «å innhente beskrivelser av intervjupersonens livsverden med henblikk på fortolkning av meningen av de fenomener som blir beskrevet» (Kvale \& Brinkmann, 2015, s. 357). I denne studien søkte vi å få tilgang til kvinnenes livsverden, altså deres egne historier, meninger og opplevelser (Kvale \& Brinkmann, 2015, s. 46; Brinkmann \& Tanggard, 2010, s. 20).

På forhånd laget vi en intervjuguide med tematiske spørsmål, hvor vi søkte kunnskap om deres erfaringer og opplevelser av selve sykdommen og deres synspunkter på tiltak, som kostholds- og aktivitetsendringer. Kvalitative forskningsmetoder søker i størst mulig grad å reflektere aktørenes erfaringer og meninger, og $\mathrm{i}$ et fenomenologisk perspektiv regnes dette som gyldig kunnskap (Malterud, 2013, s. 38 og 45).

\section{Informanter}

Helsesøster fulgte våre kriterier for utvalg som dreide seg om kvinner i alderen 55+, med en livsstilsykdom og landbakgrunn fra Pakistan. Alle informantene forsto norsk, men snakket ikke språket flytende. Derfor ble det brukt tolk under intervjuene. Kvinnene var hjemmeværende og kom til Norge på 1970-tallet. De hadde altså bodd her i over 30 år og hadde aldri hatt fast lønnet arbeid. De hadde forestilt seg å bo i landet i noen få år for så å reise hjem igjen. Slik ble det ikke.

Tabell 1: Oversikt over informantene

Tabellen gir oversikt over landbakgrunn, alder, botid i Norge og arbeidstilknytning.

\begin{tabular}{|l|l|l|l|l|}
\hline & Landbakgrunn & Alder & $\begin{array}{l}\text { Antall år/botid } \\
\text { i Norge }\end{array}$ & Arbeid \\
\hline Informant 1 & Pakistan & Ca 55 & 30 & nei \\
\hline Informant 2 & Pakistan & 58 & 36 & nei \\
\hline Informant 3 & Pakistan & 60 & 30 & nei \\
\hline Informant 4 & Pakistan & 58 & 32 & nei \\
\hline Informant 5 & Pakistan & 62 & 42 & nei \\
\hline Informant 6 & Pakistan & 56 & 32 & nei \\
\hline Informant 7 & $\begin{array}{l}\text { Pårørende, datter av } \\
\text { pakistanske foreldre }\end{array}$ & 38 & 38 & nei \\
\hline
\end{tabular}

Seks av intervjuene med kvinnene ble gjennomført med tilstedeværelse av kvinnelig tolk, som var et $\emptyset$ nske fra informantene. Intervjuet med pårørende, som i utgangspunktet skulle vært med mor, ble gjennomført uten tolk og hjemme hos informanten. Intervjuene varte ca en time, ble tatt opp på 
bånd og transkribert i etterkant. Det var forskerne selv, og ikke en utenforstående, som transkriberte intervjuene for å få med detaljer som kunne være vesentlige for dataene (Brinkmann \& Tanggard, 2010, s. 35)

\section{Datagrunnlag: intervjuer og refleksjonsnotat}

Datagrunnlaget baserer seg primært på kvalitative semi-strukturerte intervjuer med seks kvinner med innvandrerbakgrunn og ett intervju med datter til en kvinne som var for syk til å bli intervjuet. I tillegg ble det gjort refleksjonsnotater etter hvert intervju. Disse søker å gjenskape stemning, refleksjoner over intervjusituasjonen, beskrivelser av interaksjonen mellom forsker og informanter og informantenes ikke-verbale uttrykk som kan reflektere kulturelle koder (Postholm, 2010, s. 103104). Refleksjonsnotatene er dels bakt inn underveis i analysen, dels integrert i de korte oppsummeringene etter hver kategori i analysen. Ifølge Brinkmann \& Tanggard (2010) forsømmer mange forskere å gjengi den sosiale interaksjonen som skjer under intervjuet. Dette var nettopp den overordnede hensikten med refleksjonsnotatene, å fange opp våre fornemmelser knyttet til kulturelle faktorer som kan påvirke intervjusituasjonen og som kunne ha betydning for forståelsen av dataene som blir analysert.

På tross av relativt få informanter, mener vi likevel at meninger fra en relativt homogen informantgruppe, kan indikere tykke beskrivelser fra dataene og åpne for komparasjoner knyttet til helsekommunikasjon. Dette begrunnes blant annet med fellestrekk i deres sosiale og kulturelle bakgrunn, og forskernes refleksjoner underveis i datainnsamlingen. Tykke beskrivelser inkluderer utsagn fra informantene, hvilke fortolkninger de selv gir og tolkninger fra forskerne (Fangen, 2019, s. 212). Informantene svarte på spørsmål om sine erfaringer i kommunikasjon med helsepersonell knyttet til kosthold, fysisk aktivitet, sykdom, behandlingstiltak og sosiale og familiære forhold. Dette ga innsikt i deres livshistorier.

\section{Bruk av tolk}

Helsedirektoratet har utarbeidet en veileder om kommunikasjon via tolk til bruk i helsesektoren (Helsedirektoratet, 2011). Kommunikasjon gjennom tolk kan være nødvendig for å gi forsvarlig helsehjelp og for presis informasjon til pasientene. Tolken skal gjengi alt som blir sagt uten å endre, tilføye eller utelate noe (Helsedirektoratet, 2009, s. 6-7).

Vi brukte autorisert kvinnelig pakistansk tolk for oppdraget, som var kulturelt akseptert og språklig dyktig (Kvale \& Brinkmann, 2015, s. 173). Informantene forsto norsk, men foretrakk å snakke på sitt eget morsmål, urdu. Generelt bidrar tolken til å kvalitetssikre informasjonen som gis og fungerer som et mellomledd i kommunikasjonen mellom forsker og informant. Men det kan også innebære visse implikasjoner med hensyn til tolkens nøytralitet i informasjonsformidlingen, siden tolken blir en premissleverandør som kan innebære visse begrensninger i kommunikasjonen (Helsedirektoratet, 2009, s. 11). Som forskere måtte vi stole på at informasjonen ble korrekt begge veier. Ved uklarheter i spørsmålsstillingene fra forsker eller svarene fra informanter hadde tolken 
en viktig rolle i å formidle kun det som ble sagt og oppklare uklarheter eller misforståelser. Vi hadde tillit til at informasjonen som kom fram gjennom tolken, var autentisk og i tråd med informantenes budskap.

\section{Forskningsprosess og forskerrolle}

I kvalitative studier er forskeren hovedinstrumentet, som utformer intervjuguide, foretar intervjuene, koder og kategoriserer dataene for analyse. Et vesentlig poeng er derfor at forskeren inntar informantenes perspektiv, også betegnet som det emiske perspektivet (Creswell, 2007, s. 72). Forskeren kan veksle mellom nærhet og distanse til informantene, eller å være insider og outsider (Kvernbekk, 2005, s. 18-51). Oftest er forskeren outsider, mens de som blir forsket på er insidere. Kvernbekk fremholder at forskeren beveger seg langs et kontinuum mellom å være outsider og insider. I denne studien kan vår førforståelse og kunnskap om helsekommunikasjon generelt gjøre oss til insidere, mens vi er outsidere når disse spesifikke informantene kommuniserer sine erfaringer og opplevelser med en livsstilssykdom. Det er nettopp i dette spennet mellom forskerens bakgrunnskunnskaper og informantenes formidling av sine erfaringer at ny kunnskap og innsikt utvikles (Creswell, 2007).

Forskerrollen i kvalitative studier er også preget av et asymmetrisk maktforhold mellom forsker og informanter, og kan romme en spenning mellom profesjonell distanse og personlig relasjon (Kvale \& Brinkmann, 2015, s. 108). Det ble derfor viktig for oss å være bevisste den asymmetriske maktrelasjonen ved refleksivitet i forskerrollen. Dette handler om at forskeren reflekterer over sitt bidrag til produksjon av kunnskap med kritisk blikk på sitt paradigme, det vil si sine verdier, holdninger, førforståelser eller interesser, også betegnet som praktisk klokskap (Kvale \& Brinkmann, 2015, s. 277). Kvale og Brinkmann sier «en streben etter sensitivitet med hensyn til ens fordommer, ens subjektivitet, innebærer en refleksiv objektivitet» (Kvale \& Brinkmann, 2015, s. 273). Vi var oppmerksomme på at vår forskerrolle kan påvirke de involverte, altså informantene og tolken. Derfor var vi bevisste på å holde vår førforståelse og kunnskaper i bakgrunnen slik at informantene fikk komme til orde med sine egne fortellinger.

\section{Validitet}

Denne studien inkluderer kun syv informanter og har dermed begrenset ekstern validitet. Postholm konkluderer med at «validitet i kvalitativ analyse er mer avhengig av mangfoldet i informasjonen og forskerens evne til å analysere enn utvalgets størrelse» (Postholm, 2010, s. 164). Siden det er forskeren selv som velger metode, samler inn data, analyserer og tolker, kan dette gi implikasjoner for validiteten for forskningsresultatene (Kvale \& Brinkmann, 2015, s. 20-39). Dataene ble bearbeidet og tolket av oss som forskere og blir på denne måten representasjoner av informantenes fortellinger. Kunnskapen som utvikles kan dermed fremstå som indirekte representasjoner av kvinnenes erfaringer, preget av våre eller forskernes paradigme

For å sikre størst mulig validitet i hele forskningsprosessen, ble refleksivitet og deltakerperspektiv en vesentlig strategi. På denne måten mener vi at vi forhindret å «go native» med informantene (Silverman, 2008, s. 28). Det innebar at vi aldri markerte gjenkjennelse, enighet eller 
identifikasjoner med informantene våre. Det at vi var to forskere i hele forskningsprosessen, mener vi styrker validiteten av dataene og analysen. Kvale legger til enda ett moment knyttet til validitet, nemlig forskernes kunnskap om feltet og temaet for forskningen. Han sier at «(...) kunnskaper om forskningsemnet og ekspertise i det aktuelle feltet [er] en forutsetning for gyldige tolkninger» (Kvale, 1997, s. 116). En siste faktor som vi vil trekke fram med hensyn til validitet i forskningen, har med tillit og trygghet mellom forskere og informanter å gjøre. Vi opplevde at kvinnene fikk god tiltro til oss, og at de var trygge i intervjusituasjonene og gjerne ville komme tilbake om det var behov for det.

\section{Etikk}

Alle deltakere i studien ble informert muntlig og skriftlig og gav sitt skriftlige samtykke før data ble innhentet. Det var frivillig å være med i studien og anledning til å trekke seg når som helst. Ingen av informantene ønsket å få de transkriberte intervjuene tilsendt for gjennomlesing. Informantene er anonymiserte med nummererte koder. Studien er lagt fram for Norsk senter for forskningsdata (NSD). Da studien ikke registrerer personopplysninger, omfattes studien ikke av meldeplikt (prosjektnr. 37670).

\section{Analyse og resultater}

Analysen starter allerede med formålet med forskningen og er bærende for selve intervjusituasjonen (Kvale \& Brinkmann, 2015, s. 219). Intervjuene ga informasjon om hva kvinnene kommuniserte med helsepersonell, hvordan de mottok og bearbeidet informasjon om sykdommen og livsstilsendringene de fikk presentert. Kodene oppsto induktivt av selve materialet vi transkriberte (Brinkmann \& Tanggaard, 2010, s. 39). Etter at intervjuene ble transkribert, lagde vi en meningskondensering for deretter å kategorisere. I presentasjonen av resultatene har vi tematisert dataene i analytiske kategorier som belyser studiens formål og forskningsspørsmål (Thagaard, 2009, s. 150). Hovedkategoriene belyser samlet sett helsekommunikasjon som overordnet begrep for studien. Disse er Kunnskap og forståelse og Helseutfordringer. Hver hovedkategori består av flere underkategorier som belyser detaljene $\mathrm{i}$ analysen.

\section{Kunnskap og forståelse}

Innledningsvis snakket vi med kvinnene om det å få en livsstilsykdom, i dette tilfellet diabetes 2 og om deres forståelse av den informasjonen som ble formidlet av helsepersonell. Flere av kvinnene fortalte at de reagerte med redsel da de fikk sin sykdomsdiagnose. En av kvinnene sier: «Jeg var veldig redd da jeg fikk diabetes, trodde jeg skulle dø. Jeg visste ingenting om sykdommen, derfor ble jeg veldig deprimert» (informant 2). Opplevelser som tidlig død blant venner og familiemedlemmer med sykdommen, førte til redsel, passivitet og nedslåtthet hos kvinnene.

En av kvinnene fortalte: «Det jeg var mest redd for da jeg fikk diabetes type 2 var at dette var i familien vår, tanta mi og moren min fikk sykdommen og begge døde unge, derfor var det vanskelig 
å akseptere at jeg hadde fått samme sykdom» (informant 3). Hun gråt og det var tydelig at det var vanskelig både å uttrykke og gjenoppleve hendelsene. En annen fortalte: «Jeg var veldig mye deprimert da jeg fikk diabetes. Jeg tenker - jeg er død» (informant 4). Dette med redsel og angst var noe de svært gjerne ville snakke om.

Kronisk sykdom kan utløse angst og stress (Stang, 2009, s. 10; Antonovsky, 1987). Stressfaktorer som angst, depresjon, redselen for å dø kan være med på å gi uhelse, og kan være et hinder i å motta nødvendig helseinformasjon og ta tak i egen livsstil.

\section{Sammenheng mellom fysisk og psykisk helse}

Kvinnene fortalte om plager de slet med, og om følelser av usikkerhet og uro etter at de hadde fått informasjon om sykdommen. En av kvinnene sier følgende: «Jeg har smerter i hele kroppen» (informant 4), «jeg har brennende fornemmelse i beina og vondt i halsen» (informant 3). Denne kvinnen tar seg til halsen og skjærer grimaser og sier: «Jeg har en brennende og ekkel følelse i magen» (informant 1). De var usikre på om de plagene som de hadde, var i forbindelse med diabetes. Dette kan forklares ut fra Antonovskys teori, om at fysisk og psykisk helse må ses i sammenheng (Antonovsky, 1987). «Da jeg fikk sykdommen, visste jeg ikke hva sukkersyke var» (informant 5). Flere i familien hadde diabetes, men selv hadde hun ingen kunnskap om sykdommens forløp. Kvinnene var opptatt av å fortelle om sine plager og vondter og kom uoppfordret tilbake til temaet i løpet av intervjuet. De fortalte at de var glade for at noen hørte på den uro de følte.

\section{Kunnskap om sykdommen}

Å gjøre kostholdsendringer syntes alle var vanskelig. Dette begrunnet de med at de var slitne. «Det er ikke vanskelig å få til forandringer, men nå er jeg bare sliten» (informant 3). Hun hadde ikke tiltak til å gjøre noe med livsstilen sin og ville ikke utdype dette nærmere, som kan tyde på en manglende forståelse av sammenhengen mellom fysisk og psykisk helse, jf Antonovsky «Sense of Coherence (SOC). Dette kan gi forklaring på hvorfor det er vanskelig å håndtere egen livssituasjon. En forutsetning for å mestre hverdagen er å se sammenhengen og muligheten til å påvirke. En av informantene sier: «Jeg skulle ønske legen fortalte mer om sykdommen og hva som skjer i kroppen» (informant 6). Det å ha kunnskap om egen sykdom og sykdomsutvikling er viktig. Aktiv deltagelse i egen helsepåvirkning kan føre til bedre mestringsfølelse (Antonovsky, 1987, s.18-19). Kvinnene hadde mange spørsmål, som de enten ikke fikk svar på eller ikke torde å spørre om. Dermed blir mestring av egen sykdom dårligere fordi de ikke får svar på sine bekymringer.

\section{Årsaksforklaringer}

Kvinnene hadde ulike forklaringer på hvorfor akkurat de hadde fătt sykdommen, noen mente det var arvelig/genetikk og andre mente det var Guds bestemmelse. Antonovsky vektlegger i sin teori fire fokusområder: indre følelser, sosiale relasjoner, psykisk stabilitet og å være involvert i givende aktiviteter (Antonovsky 1987, s. 89-127). Mangel på innflytelse kan sees i sammenheng med mangel på kunnskap. En av kvinnene uttrykte dette slik etter at vi hadde spurt om livsstilsendring: «Gud har bestemt at jeg skal ha denne sykdommen, derfor hjelper ikke fysisk aktivitet eller endring 
i kostholdet mitt» (informant 2). Hun lo godt og overbærende til oss da hun fortalte dette. Om religion og Gud kan sees i denne sammenheng som mestringsressurs eller som bortforklaring som tilbyr forankring, retning og mening i livet (Antonovsky, 1987, s. 89-127), vites ikke.

En av kvinnene sa: «Hva kan et menneske gjøre når Gud har bestemt?» (informant 6). Troen på skjebnen, kombinert med en lav helserelatert dannelse (health literacy) kan vise seg å føre til både avmaktsfølelse, og resignasjon. Jenum og Pettersen omtaler health literacy som «personlige, kognitive og sosiale ferdigheter som er avgjørende for enkeltindividets evne til å fă tilgang til, forstå og anvende helseinformasjon for å fremme og ivareta god helse» (Jenum \& Pettersen, 2014, s. 272). Dette kan tyde på at kvinnene ikke kjenner til sykdomsårsakene, og at informasjonen fra helsepersonell muligens verken er gitt eller forstått av kvinnene.

\section{Flerkulturell forståelse hos helsepersonell}

«Jeg spør ikke om igjen hvis jeg ikke forstår, fordi noen leger blir irriterte hvis en spør flere ganger» (informant 1).

«Legen snakker legespråk, og det forstår jeg ikke, men spør ikke om igjen, jeg er jo bare en husmor som ikke forstår» (informant 5).

Disse to utsagnene fra informantene beskriver hvordan kvinnene oppfattet interaksjonen mellom seg og legen. Kvinnene spør ikke om igjen hvis de ikke forstår det som blir sagt. «Jeg sier jeg forstår, men det er ikke alltid jeg gjør det» (informant 4). Hun ler og sier hun prøver å overbevise seg selv at dette har hun forstått. «Jeg sier til hjernen min at dette forstår du, men noen ganger forstår jeg bare ikke. Legen sier aldri at jeg skal ha med tolk, han forteller ikke på andre måter heller, jeg skulle ønske han gjorde det» (informant 2). Hun slår ut med hendene litt oppgitt. Den kommunale helse- og omsorgstjenesten i Oslo har et underforbruk av profesjonell språklig assistanse. Ofte tyr en til familie og venner av pasienten. Dette kan være med på å hindre likeverdige helsetjenester (NOU 2014:8, s. 42). For å få en forståelig helsekommunikasjon må både pasient og helsepersonell snakke slik at de begge blir forstått av hverandre (Sletteland, 2014, s. 27). Å knekke koder er viktig i en interkulturell kommunikasjonsprosess (Dahl, 2017, s. 77).

En utvidet forståelse og kunnskap om pasienten er grunnleggende for vellykket kultursensitiv kommunikasjon (Magelssen, 2008, s. 18). Slike kontekstualiseringer kan bli en utfordring for helsepersonell som skal veilede personen i livsstilsendringer. Derfor, sier Magelssen, bør helsepersonell ha god kunnskap om personens sosiokulturelle verden og beherske kultursensitiv kommunikasjon (Magelssen, 2008, s.16). Flere av kvinnene mente de hadde liten sykdomskompetanse og helseforståelse og ble dermed underlegen legen. Denne følelsen av underlegenhet kan knyttes til det emosjonelle nivået hos kvinnene. I Antonovskys teori kaller han dette for egoidentitet. Det er en ressurs på emosjonelt nivå og handler om den opplevelsen personen har av seg selv (Antonovsky,1987, s. 24-27). Kvinnene fortalte at de følte seg mindreverdige når de var i kontakt med helsepersonell. På spørsmål om det var noe de ikke fikk svar på, bekreftet mange dette, og en av kvinnene svarer slik: «Mange sier at pakistanske damer har brennende fornemmelser i føttene - 
når jeg stilte spørsmål om dette, så sa de at dette ikke hadde noen forbindelse med sukkersyken, men jeg føler at det har sammenheng» (informant 4). Hun føler seg avvist og ikke trodd.

Fortolkning av kroppslige symptomer er basert på kulturell kunnskap, erfaringer og reaksjoner (Ingstad, 2015, s. 40). Flere av kvinnene fortalte om lignende hendelser og plager, som brennende fornemmelse. Kvinnene ble engstelige da disse problemene ikke ble tatt alvorlig. Om plagene har noe med diabetesen å gjøre eller ikke, er viktig å få avklart. De indre følelsene og psykisk stabilitet som Antonovskys SOC-teori handler om, er ikke blitt dekket. Vi erfarte at kvinnene var ganske oppgitte over ikke å få aksept over de engstelsene de fornemmet. I starten når de snakket med oss om sine plager, merket vi at de var redde for at vi ikke tok dem på alvor eller gjorde narr av dem. De kom med noen få kommentarer først for å teste vår reaksjon. Når vi stilte oppfølgingsspørsmål, slappet de mer av og ville gjerne fortelle mer.

Oppsummering med refleksjoner: Den informasjon vi fikk knyttet til det å leve med diabetes, var interessant av flere grunner. Det var ulike årsaksforklaringer for hvorfor de hadde fått sykdommen. Ut fra intervjuene med kvinnene kom det frem at de har generelt liten kunnskap om sykdommen og om hvordan de kan makte å endre sin livsstil for å hindre sykdomsutviklingen. De ønsket mer opplæring om sykdommen. På grunn av manglende norsk språkforståelse er det vanskelig å konkludere med om informasjon om sykdommen er gitt eller om den ikke er blitt forstått. Det har ofte vist seg å være en betydelig avstand mellom det helsepersonell antar pasienter forstår og det pasientene faktisk forstår (Jenum \& Pettersen, 2014, s. 272). Derfor viser studien at formidlet informasjon sjelden er oppfattet i sin helhet av personen. Kvinnene spør heller ikke hvis de ikke oppfatter det som blir formidlet.

\section{Helseutfordringer}

Ut fra den transteoretiske modellen til Prochaska \& Di Clemente (1983) må en være bevisst de hindringene som er tilstede (stadie 3) slik at handlingene kan virke overkommelige og som igjen kan føre til at motivasjonen $\varnothing$ kes (stadie 4). En av hindringene kan være mangel på sosial støtte, som er viktig når negative hendelser skal bearbeides (Antonovsky, 1987, s. 33). Ved livsstilsendringer, må en ofte ha hjelp fra andre, noe som også kvinnene kommenterte. En av kvinnene uttrykte seg slik på spørsmål om de hadde venninner de kunne betro seg til: «Hvorfor skal jeg snakke med venninner om sykdommen når jeg har døtre jeg kan snakke med» (informant 4). De snakket lite med sine bekjente og venner om sykdommen og sykdomsmestring. En av kvinnene ble ivrig når vi kom inn på dette. Hun repeterte flere ganger og sier med ettertrykk: «Vi bør snakke om sykdommer som diabetes med andre, ikke bare familien» (informant 3 ).

Det å snakke om diabetes var ikke tabubelagt. Dette til tross, så var det kun familien kvinnene snakket med. Antonovsky definerer nære emosjonelle bånd som viktige i den sosiale støtten, noe som kvinnene uttrykte at de hadde med familien. Opplevelse av nær sosial støtte er utslagsgivende for mestringsevnen, mens kvaliteten på den sosiale støtten har betydning for resultatet (Antonovsky, 1987, s. 33-34). Kvinnene mente at de fikk anerkjennelse og positiv tilbakemelding fra sine nærmeste, som ble deres viktigste sosiale støttespillere. Selv om noen kom med noen divergerende 
argument, som en informant irritert opplyste oss om at « ...det er ingenting å gjøre med diabetes, derfor er det ingen vits i å snakke med noen om det» (informant 1).

\section{Kostholdsendring}

Å gjøre noen livsstilsforandringer kan være med på å forbedre sykdomstilstanden. Regelmessig mosjon og et sunt kosthold er viktig i behandlingen. Høyt inntak av kaloririk og fet mat og lav fysisk aktivitet er ugunstig for utvikling av livsstilsykdommer (Norsk helseinformatikk, 2018).

En dansk studie (Hempler et al, 2015, s. 351-353) viser til at helseatferdsendringer eller livsstilsendringer er kompliserte. Det handler om støtte fra det sosiale nettverket, tilpasset kostholdsveiledning og kommunikasjon mellom kvinnene og helsepersonell (Hempler et al., 2015, s. 350353). Alle kvinnene hadde vært på kostholdskurs, men alle sa det samme «Jeg ønsker meg flere kurs, de vi hadde varte bare tre uker (en dag pr uke) og da fikk vi ikke spurt om alt vi ønsket å spørre om» (informant 1). Dermed ble det mange ubesvarte spørsmål og en del undringer. På kurset hadde de fått brosjyre om kosthold og diabetes. På spørsmål om dette var nyttig informasjon, var det ingen som svarte oss. Vi tolket det dithen at de ikke hadde brukt eller forstått brosjyren.

Sykdomsforståelse og kunnskap om kostholdets betydning som inkluderer blodsukkerets stabilisering og vektreduksjon står derfor sentralt i den helsefremmende behandlingen av livsstilsykdommer. Ifølge Prochaska \& Di Clemente (1983) (se fig. 1) er det av betydning for helsepersonell å vite hvilket stadium pasienten befinner seg på, slik at tiltakene settes inn der. En av kvinnene fortalte følgende om det å få kostholdsråd: «Jeg får mest kostholdsråd fra mann og barn» (informant 2). Dette kan tyde på at den kostholdsinformasjonen som eventuelt er blitt gitt fra helsepersonell, ikke er forstått eller ikke har vært kulturelt tilpasset og dermed ikke interessant for kvinnene fordi de ikke kan identifisere sitt kosthold med de kostråd som er gitt av legen.

Kosthold er preget av kultur, tradisjon, religion, ernæring, smakspreferanser, tilberedningsmåter og identitet (Eriksen \& Sajjad, 2015, s. 244, 248-249; Kumar \& Ayub, 2010, s.172; Hempler et al, 2015, s.350-351). Denne komplekse oppfatningen medfører en ekstra utfordring ved varig kostholdsendring. En av kvinnene fortalte: «Leger mangler kunnskap om det pakistanske kostholdet, derfor blir det vanskelig å hjelpe oss med det» (informant 3). En annen fortalte at det var «en del myter i det pakistanske kostholdet, men dette følger ikke vi. Men jeg merker det når jeg kommer til Pakistan og leger der forteller hva jeg kan spise og ikke spise, men her i Norge er det ingen som sier noe om det» (informant 3). En av kvinnene fortalte dette når hun skulle forklare hvilken ris hun brukte: «Jeg bruker ikke den risen med masse krydder i, den er farlig, det er mange farlige stoffer i ris som fordamper» (informant 6). Vi spurte om hun kunne forklare mer om det, eller fortelle hvor hun hadde fått denne informasjonen fra, men det visste hun ikke. Dette mente hun bare var noe alle visste, så det var ikke mer å snakke om.

Kostholdsveiledning fra fagpersonell uten kjennskap til personens kulturelle bakgrunn vil kunne oppleves forvirrende og lite etterlevelig. Derfor er det en forutsetning at det gis kostholdsråd som kan aksepteres av personens tradisjoner og eventuelle religiøse restriksjoner. Først da kan et kostholdsråd bli forstått, gi mening og bli etterfulgt.

Kvinnene fortalte at de nesten ikke drakk søte drikker som saft og brus. «Nå drikker jeg lite brus, kanskje ett glass, eller et halvt hvis vi har besøk, men da drikker jeg cola» (informant 1). På spørsmål 
om sukker i te, svarte de at de brukte lite eller ingenting, og noen benyttet kunstig søtningsmiddel. Ved et tilfelle ble en informant bedt om å vise hvor mye sukker hun brukte $\mathrm{i}$ teen. Denne informanten mente hun brukte en liten teskje, men som i realiteten viste seg å være en spiseskje med sukker. Underrapportering er et kjent fenomen i kostholdsunders $\varnothing$ kelser (Stubbs, O`Reilly, Whybrow \& Fuller, 2014, s. 2038-2042).

Informantene i denne studien mente selv de hadde et sunt kosthold. På spørsmål hva som ble betegnet som sunt, ble frukt nevnt som det første. De fleste spiste all slags frukt, men mest appelsiner, epler og bananer. En av kvinnene var mer opptatt av at hun spiste det hun hadde lyst på, og sa følgende: «Jeg spiser mye bananer på brødskiven min. Og jeg liker syltetøy og brunost også, da kan jeg spise mye mat» (informant 6). Frukt og bær inneholder karbohydrater i form av fruktose og glukose, som gir en moderat blodsukkerstigning, i motsetning til fruktjuice som gir $\varnothing \mathrm{kt}$ blodsukkerstigning. En av informantene sa begeistret: «Jeg elsker pannekaker med syltetøy» (informant 4). «Grønnsakene jeg spiser er langtidskokt i gryte» (informant 6). Ved langtidskoking av grønnsaker forsvinner de vannløselige vitaminer B og C.

I den salutogenenesiske tilnærmingen beskrives kunnskap og intelligens som kognitive ressurser (Antonovsky, 1987, s.128-162). En diabetiker må tilegne seg kunnskaper om blodsukkerregulering, og hvilke matvarer som er gunstig å innta. En av kvinnene illustrerte dette ved å fortelle at de spiste mye norsk mat som hun mente var sunnere enn den pakistanske. På spørsmål om hva hun la i norsk mat sa hun: «Ja, det kan være for eksempel pasta, pizza og hamburger» (informant 5). Disse matvarene gir høyt inntak av metta fett og karbohydrater, noe som blir frarådet i Helsedirektoratets kostholdsråd (Helsedirektoratet, 2009, s. 60-61). Et interessant spørsmål å stille er når en matrett eller matvare blir en tradisjon? Siden det spises nettopp mye av disse matrettene i Norge i dag, er de da blitt en del av vår norske tradisjon? Og er nødvendigvis de nye matrettene sunne? Det er viktig at de som skal veilede om kosthold, har forståelse for tradisjoner, matvaner og matretter.

\section{Fysisk aktivitet}

Lav fysisk aktivitet er utslagsgivende for utvikling av overvekt og livsstilsykdommer. Ofte er kosthold og livsstil et viktig symbol på kulturell tilhørighet (Kumar \& Ayub, 2010, s.174). Helseeffekt av fysisk aktivitet er ikke et kjent fenomen i alle kulturer. Kvinner av pakistansk opprinnelse ser ut til å ha spesiell lav deltagelse i fysisk aktivitet (Hjellset, Bjørge, Eriksen \& Høstmark, 2011). Dette henger sammen med den kultur en er vokst opp med og ikke minst spiller sosiokulturell tilhørighet en rolle.

En av kvinnene fortalte hvordan det var å komme til Norge. «Jeg synes livet er tøft, jeg giftet meg tidlig, flyttet til Norge, har vært mye deprimert. Det er vanskelig å flytte på seg i ung alder, dette kommer tilbake nå» (informant 2). «Jeg har vært husmor og tatt vare på ungene hele tiden» (informant 4). Kvinnene fortalte de hadde få venner de forholdt seg til, og de hadde ingen å spørre om turgåing. Informantene i vår unders $ø$ kelse opplevde fysisk trening som vanskelig og utfordrende. En informant uttrykte: «Legen sier at jeg skal ut å trene, men det gjør jeg ikke fordi jeg har vondt i kroppen» (informant 5). Befinner informanten seg på stadiet 1 eller 2 i den transteoretiske modellen (Prochaska \& Di Clemente, 1983), er det lett at budskapet misforstås eller ikke etterleves da informanten ikke er motivert eller har forståelse for å gjøre forandringer. En studie hvor fysisk 
aktivitet ble lagt til rette for svært inaktive pakistanske menn, viser at de fikk bedre insulinnivå i blodet og redusert livvidde (Andersen, Hostmark \& Anderssen, 2012, s.742-745), noe som bekrefter at tilrettelegging for fysisk aktivitet er viktig og kan gjøre store utslag for å bedre helsen.

Gjennomføring av individualisert behandling og veiledning krever derfor kunnskap om personens bakgrunn, livssituasjon, utdanning, funksjonsnivå og eventuelle sykdommer (Helsedirektoratet, 2009). En av informantene sier: «Jeg er så sliten at jeg bare vil ligge på sofaen hele dagen» (informant 2). En annen forteller: «Jeg har mye angst, psykiske problemer, og har hatt det lenge. Derfor er det vanskelig for meg å komme meg ut» (informant 5). «Jeg har vært litt på treningsstudio, men liker ikke at det er både menn og kvinner der» (informant 1). «Jeg synes vinteren er verst da jeg ikke tør gå ut, livet er tøft» (informant 2). Hun gråter mye når hun forteller om dette og vet at hun bør komme seg ut, men greier ikke å gjøre noe med det. En av kvinnene sier hun tidligere trente på frisklivssentralen, og sier følgende: «Nå ønsker jeg å starte igjen» (informant 3). På spørsmål om når hun har tenkt dette, er hun unnvikende og snakker om noe annet, men sier samtidig «jeg ønsker å bli tynn».

Oppsummering med refleksjoner: Det å kunne bruke sine egne mestringsressurser, vil føre til erfaringer som stimulerer til Sense of Coherence; forståelse, håndterbarhet og mening med fysisk aktivitet og kostholdsendring (Antonovsky, 1987). Hver især bør involveres i egne aktivitets- og kostholdsendring. Ved migrasjon holder mange på egne mattradisjoner, men tar også til seg nye. Tilgangen på matvarer kan være avgjørende for de valg en treffer, og er nødvendigvis ikke bevisste.

Da vi snakket om ulike treningsaktiviteter, gråt mange av kvinnene og fortalte om depresjoner og angst. Når de blir deprimerte, legger de seg ned på senga eller sofaen. Å komme seg over de første barrierene er viktig og det må være lystbetont.

\section{Avslutning og diskusjon}

Det å få en livsstilsykdom innebærer at en må lære seg å iverksette nye helseatferdsmåter (Gammersvik, 2012, s. 142). Dette krever deltagelse og engasjement fra kvinnene, og at helsepersonell er pådrivere og har kunnskap om personenes mestringstro (Espnes \& Smedslund, 2009, s. 131). For at kvinnene skal ha mestringstro på seg selv, må de få opplæring om livsstilsykdommen, om senkomplikasjoner, om helsefremmende tiltak som kosthold og fysisk aktivitet slik at de kan nå målene.

Intervjuene ga oss ingen indikasjon på at kvinnene hadde fått individuell kultursensitiv behandling. For å kunne gi det må kvinnene fortelle om hvilke plager de har. Individuell behandling vil ikke være mulig hvis ikke dialogen mellom kvinnene og helsepersonell er tilstede. Spørsmål om hvorfor det er mangel på dialog, dreier seg dels om at kvinnene har stor respekt for helsepersonell og tør ikke fortelle hva som feiler dem. Dels dreier det seg om kulturelt betingete forhold der en ikke problematiserer sine bekymringer. Kvinnene fortalte at de ikke snakket med venner om sykdommen, selv om dette ikke var tabubelagt. Den nærmeste familie ga dem råd om kosthold, men sine depresjoner snakket de ikke med noen om. Det er derfor vanskelig å konkludere om dette er et tabubelagt tema, eller om det er knyttet til kulturelle koder og sosiale relasjoner. Alle kvinnene sa de ønsket helseforbedring, men de greide ikke å gjøre dette på egen hånd. 
For helsepersonell er det viktig finne ut hvilke hindringer som er tilstede for at de skal være motivatorer videre i prosessen med atferdsendring. Dette er i samsvar med Antonovskys teori om at pasienten må få hjelp til mestring, forståelse, håndterbarhet og meningsfullhet for å endre sin helseatferd (Antonovsky, 1987, s. 16-19). Det er vanskelig å endre helseatferd hvis ikke veiledningen er personlig og kvinnene ikke har et eierforhold til den (Antonovsky, 1987, s.16-192). Ut fra våre samtaler med kvinnene hadde de et ønske om å få et bedre liv, men de hadde ikke noen klare mål og milepæler for hvordan og når de skulle starte, eller hva de skulle gjøre. Dette vanskeliggjør behandlingen.

Målene med denne studien er å få avdekket hvilke utfordringer kvinner med innvandrerbakgrunn møter i kommunikasjon med helsepersonell, og hvilke utfordringer de selv mener de har med helseatferdsendringer. Vårt første forskningsspørsmål er: Hvilke utfordringer mener kvinner med innvandrerbakgrunn de har i møte med helsearbeidere? Noen føler seg underlegne helsearbeidere fordi de har lite kunnskap om egen sykdom, og ikke blir tatt på alvor når de antyder sine bekymringer. Forskning vi refererer til viser at helsearbeidere mener de ikke har god nok opplæring i kultursensitiv kommunikasjon og kulturforståelse. Kvinnene i denne studien var ikke fysisk aktive selv om de visste dette var viktig. Utfordringene var å finne aktiviteter som er i nærheten av hjemmet og som motiverer. Mange av dem ønsket å ha noen å gjøre aktiviteter sammen med, men fordi de hadde lite sosialt nettverk, visste de ikke hvem de skulle spørre

Et annet aspekt er at helsearbeiderne ikke spør om kvinnene har forstått informasjonen som er gitt, og at kvinnene heller ikke tør si noe om dette. Dette førte til at de opplevde at de ikke fikk informasjon om årsaken til sin sykdom, og de fortalte heller ikke helsepersonell om sine depresjoner. Derfor ble ikke dette belyst på konsultasjonene.

Det andre forskningsspørsmålet for studien er hva slags flerkulturell kompetanse som synes nødvendig for helsepersonell med basis i våre intervjuer med kvinner med innvandrerbakgrunn? Både nasjonal og internasjonal forskning viser til at kommuner må forberede seg på et større mangfold og flere innvandrere i årene fremover (Moen, 2002a, s. 9; Moen, 2002b, s. 13). Dette indikerer at helsefaglige utdanninger bør vektlegge flerkulturalitet og kultursensitivitet i opplæringen. Tema som går igjen i tidligere forskning er bruken av ulike kommunikasjonspraksiser og det å utfordre sine egne verdier, holdninger og stereotypier. Flere av artiklene fremmer at helsepersonell må få en forsterket kulturopplæring. I de tilfellene helsepersonell har gitt kulturtilpasset omsorg, er pasientene mer tilfredse, de har følt seg ivaretatt og hatt bedre mestring. For å gi en kulturtilpasset opplæring i livsstilsendring, må helsepersonell blant annet kunne noe om pasientenes kulturelle bakgrunn, språkkompetanse og kulturelle uttrykk. Forskningen poengterer også at helsepersonell etter opplæring i flerkulturell forståelse, i større grad aksepterte pasientenes kulturelle trekk, og samtidig ble mer bevisst sine egne kulturbetingete verdier og holdninger.

Vår undersøkelse bekrefter nødvendigheten av å styrke den flerkulturelle kompetansen til helsearbeidere. På bakgrunn av de erfaringer som innvandrerkvinnene i denne studien formidlet, synes det særlig behov for kompetanse innenfor tematikkene helseforståelse, kommunikasjon og kultursensitiv veiledning. I sum kan dette knyttes til sykdomsforståelse og helsefremmende tiltak i flerkulturelle perspektiver. 


\section{Konklusjon}

Det som kom tydeligst fram i studien og som informantene snakket mest om, var deres tanker om angst og depresjoner som hindret dem i å gjøre forandringer, og som gjorde dem isolerte. Angst og depresjoner var ikke noe de snakket om verken med helsepersonell eller andre. Språkbarrierene hindret kvinnene i å spørre helsepersonell om tema de var usikre på. Tidligere forskning på feltet viser at flerkulturell forståelse er viktig i opplæringen av helsepersonell. Dette har vært særlig fokusert i utdanning av leger og sykepleiere. Den $\varnothing$ kende andel av eldre i befolkningen generelt, og også av innvandrerbefolkningen, vil i nær framtid ha behov for helseomsorg, enten via hjemmesykepleie eller i institusjoner. Blant helsearbeidere er det særlig helsefagarbeidere som vil stå i nær forbindelse med eldre innvandrere. Dette $\emptyset$ ker behovet for å styrke den flerkulturelle kompetansen til denne yrkesgruppen. Derfor vil flerkulturalitet og kultursensitiv helsekommunikasjon i opplæringen av helsefagarbeidere, være spesielt viktig i årene framover.

\section{Forfatterbiografi}

Oddhild Bergsli: universitetslektor og Ph. D kandidat ved Oslomet- storbyuniversitetet, Fakultet for lærerutdanning og internasjonale studier, Institutt for yrkesfaglærerutdanningen. Hun er faglærer i ernæring, helse og miljøfag og med særlig interesse for yrkespedagogiske og yrkesfaglige feltet innen helse- og oppvekstfag, både i videregående skole og yrkesfaglærerutdanningen. Hun har undervist ved yrkesfaglærerutdanningen i helse- og oppvekstfag siden 2002

Oddhild Bergsli er hovedforfatter i denne artikkelen. Hun står bak ideen til studie, har utformet intervjuguiden, og har sammen med andreforfatter vært ansvarlig for de kvalitative intervjuene og for den komparative analysen. Denne artikkelen inngår i en Ph. D avhandling.

Ellen Beate Hellne-Halvorsen: førsteamanuensis ved Oslomet - Storbyuniversitetet, Fakultet for lærerutdanning og internasjonale studier, Institutt for yrkesfaglærerutdanningen. Hun er skriveforsker med særlig interesse for skrivepraksiser i det yrkespedagogiske og yrkesfaglige feltet Hun har doktorgrad om skriving i fag- og yrkesopplæringen i videregående skole. Hun er norskfilolog og har undervist ved studiene Norsk som andrespråk og Norsk med yrkesfaglig profil ved instituttet siden 2001.

Ellen Beate Hellne-Halvorsen er andreforfatter i denne artikkelen. Hun har sammen med førsteforfatter vært ansvarlig for de kvalitative intervjuene og for den komparative analysen. Hun er veileder i Ph.D. avhandlingen. 


\section{Referanser}

Andersen, E., Hostmark, A. T. \& Anderssen, S. A. (2012). Effect of a physical activity intervention on the metabolic syndrome in Pakistani immigrant men: A randomized controlled trial. Journal of Immigrant and Minority Health, 14(5), 738-746. https://doi.org/10.1007/s10903-012-9586-6

Antonovsky, A. (1987). Unraveling the mystery of health: How people manage stress and stay well. San Francisco: Jossey-Bass Publishers.

Brinkmann S. \& Tanggaard L. (2010). Kvalitative metoder: Empiri og teoriutvikling (1.utg.). Oslo: Gyldendal akademisk.

Cicolini, G., Della Pelle, C., Comparcini, D., Tomietto, M., Cerratti, F., Schim, S.M., Di Giovanni, P. \& Simonetti, V. (2015). Cultural competence among italian nurses: A multicentric survey. Journal of Nursing Scholarship, 47(6), 536-543. https://doi.org/10.1111/jnu.12165

Creswell, J. W. (2007). Qualitative inquiry \& research design: Choosing among five approaches (2. utg.). Thousand Oaks, Calif: Sage.

Dahl, Ø. (2017). Mфter mellom mennesker: Innføring i interkulturell kommunikasjon. Oslo: Gyldendal akademisk.

Degni, F., Suominen, S., Essén, B., El Ansari, W. \& Vehviläinen-Julkunen, K. (2012). Communication and cultural issues in providing reproductive health care to immigrant women: Health care providers' experiences in meeting somali women living in Finland. Journal of Immigrant \& Minority Health. 14(12), 330-343. https://doi.org/10.1007/s10903011-9465-6.

Eide H. \& Eide, T. (2018). Kommunikasjon i relasjoner: Personorientering, samhandling, etikk (3. utg.). Oslo: Gyldendal akademisk.

Eriksen, T. H. \& Sajjad, T. A. (2015). Kulturforskjeller i praksis: Perspektiver på det flerkulturelle Norge. Oslo: Gyldendal akademisk.

Eriksen, T. H. (2010). Små steder- store spфrsmål: Innføring i sosialantropologi. Oslo: Universitetsforlaget.

Espnes, G. A. \& Smedslund, G. (2009). Helsepsykologi. Oslo: Gyldendal akademisk.

Fangen, K. (2019). Deltagende observasjon. Bergen: Fagbokforlaget.

Foronda, C. (2008). A concept analysis of cultural sensitivity. Journal og Transcultural Nursing, 19(3), 207-212. https://doi.org/10.1177/1043659608317093

Gammersvik, Å. (2012). A framme helse sett fra et helsepsykologisk perspektiv. I A. Gammersvik \& T. Larsen (Red.), Helsefremmende sykepleie: I teori og praksis (s.141-158). Bergen: Fagbokforlaget.

Glenday, K., Kumar, B., Tverdal, A. A. \& Meyer, H. (2006). Cardiovascular disease risk factors among five ethnic groups in Oslo, Norway: The Oslo immigrant health study. European Journal of Cardiovascular Prevention and Rehabilitation, 13(3), 348-355. https://doi.org/10.1097/01.hjr.0000214616.14361.51

Hanssen, I. \& Alpers, L. M. (2010). Interpreters in intercultural health care settings: Health professionals' and professional interpreters' cultural knowledge, and their reciprocal perception and collaboration. Journal of Intercultural Communication, (23). Hentet fra https://www.immi.se/intercultural/nr23/hanssen 
Helsedirektoratet. (2011). Veileder om kommunikasjon via tolk for ledere og personell i helse- og omsorgstjeneste (IS-1924). Oslo: Direktoratet.

Helsedirektoratet. (2009). Nasjonale faglige retningslinjer: Diabetes: Forebygging, diagnostikk og behandling (IS-1674). Oslo: Direktoratet.

Helse- og omsorgsdepartementet. (2013a). Likeverdige helse- og omsorgstjenester - god helse for alle: Nasjonal strategi om innvandreres helse 2013-2017 [Plan/strategi]. Oslo: Departementet.

Helse- og omsorgsdepartementet. (2013b). Morgendagens omsorg (Meld. St. 29 (2012-2013)). Oslo: Departementet.

Hempler, N. F., Nicic, S., Ewers, N. \& Willaing, I. (2015). Dietary education must fit into everday life: A qualitative study of people with a Pakistani background and type 2 diabetes. Patient Preference and Adherence, 9, 347-354. https://doi.org/10.2147/PPA.S77380

Hjellset, V. T., Bjørge, B., Eriksen, H. R. \& Høstmark, A. T. (2011). Risk factors for type 2 diabetes among female Pakistani immigrants: The InvaDiab-DEPLAN study on Pakistani immigrant women living in Oslo, Norway. Journal of Immigrant and Minority Health, 13(1), 101-110. https://doi.org/10.1007/s10903-009-9290-3

Horntvedt, T. (2015). Interkulturelt helsearbeid. Drammen: Vett og Viten.

Ikhilor, P.O.; Hasenberg, G.; Kurth, E.; Asefaw, F.; Pehlke-Milde, \& Cignacco, E. (2019). Communication barriers in maternity care of allophone migrants: Experiences of women, healthcare professionals, and intercultural interpreters. Journal of Advanced Nursing,75(10), 2200-2210. https://doi.org/10.1111/jan.14093

Ingstad, B. (2015). Medisinsk antropologi: En innføring. Bergen: Fagbokforlaget.

Jensen, P. \& Ulleberg, I. (2019). Mellom ordene: Kommunikasjon i profesjonell praksis. (2. utg.). Oslo: Gyldendal akademisk.

Jenum, A. K. \& Pettersen, K. S. (2014). Hva betyr lav «health literacy» for sykepleierens helsekommunikasjon? Forskning, 9(3), 272-280. https://doi.org/10.4220/sykepleienf.2014.0145

Kaihlanen, A-M., Hietapakka, L.\& Heponiemi, T. (2019). Increasing cultural awareness: Qualitative study of nurses' perceptions about cultural competence training. BMC Nursing, 18(1). https://doi.org/10.1186/s12912-019-0363-x

Kale, E. (2006). „Vi tar det vi har”: Om bruk av tolk $i$ helsevesenet $i$ Oslo: En spфrreskjemaundersøkelse (NAKMIs skriftserie om minoriteter og helse nr. 2/2006). Oslo: Nasjonal kompetansesenter for minoriteter.

Kline, C. C.; Godolphin, W. J.; Chhina, G. S. \& Towle, A. (2013). Community as teacher model: Health profession students learn cultural safety from an aboriginal community. Michigan Journal of Community Service Learning, 20(1), 5-17. Hentet fra https://files.eric.ed.gov/fulltext/EJ1046931.pdf

Kumar, B. \& Magnus, J. (2017). Migrasjon og helse. I G. Tellnes (Red.), Helsefremmende samhandling: Natur og kultur som helse (s. 146-153). Bergen: Fagbokforlaget.

Kumar, B., Oppedal, B., Blystad, H., Dalgard, S. \& Vangen, S. (2010). Helse blant flyktninger og innvandrere. I Folkehelseinstituttet (Red.), Folkehelserapport 2010: Helsetilstanden i Norge (Rapport nr 2010:2, s. 55-58). Oslo: Nasjonalt folkehelseinstitutt.

Kumar, B. N. \& Ayub, S. (2010). Kosthold og helse. I B. N. Kumar \& B. Viken (Red.), Folkehelse i et migrasjonsperspektiv (s. 171-191). Bergen: Fagbokforlaget. 
Kunnskapsdepartementet. (2015). Fag - Fordypning - Forståelse - En fornyelse av Kunnskapslфftet (Meld. St. 28 (2015-2016)). Oslo: Departementet.

Kvale, S. \& Brinkmann, S. (2015). Det kvalitative forskningsintervju (3. utg.). Oslo: Gyldendal akademisk.

Kvale, S. (1997). Det kvalitative forskningsintervju. Oslo: Gyldendal norsk forlag.

Kvernbekk, T. (2005). Pedagogisk teoridannelse: Insidere, teoriformer og praksis. Oslo: Fagbokforlaget.

Magelssen, R. (2008). Kultursensitivitet (2. utg.). Oslo: Akribe.

Malterud, K. (2013). Kvalitative metoder i medisinsk forskning: En innføring. Oslo: Universitetsforlaget.

Moen, B. (2002a). Eldresenter på ukjent vei: Flerkulturelle mфter mellom eldre mennesker (NOVA-rapport 16/2002). Oslo: Norsk institutt for forskning om oppvekst, velferd og aldring. https://doi.org/10.7577/nova/rapporter/2002/16

Moen, B. (2002b). Når hjemme er et annet sted: Omsorg for eldre med minoritetsetnisk bakgrunn (NOVA-rapport 8/2002). Oslo: Norsk institutt for forskning om oppvekst, velferd og aldring. https://doi.org/10.7577/nova/rapporter/2002/8

Norsk helseinformatikk. (2018). https://nhi.no

NOU 2014: 8. (2014). Tolking i offentlig sektor: Et spфrsmål om rettssikkerhet og likeverd. Hentet fra https://www.regjeringen.no/no/dokumenter/NOU-2014-8/id2001246/

OsloMet- storbyuniversitetet. (u.å.). Sykepleie bachelorprogram [Programplan]. Hentet fra. https://www.oslomet.no/studier/hv/sykepleie

Parthab Taylor, S., Nicolle, C. \& Maguire, M. (2013). Cross-cultural communication barriers in health care. Nursing Standard,7(31), 35-43. https://doi.org/10.7748/ns2013.04.27.31.35.e7040

Postholm, M. B. (2010). Kvalitativ metode: En innføring med fokus på fenomenologi, etnografi og kasusstudier (2. utg.). Oslo: Universitetsforlaget.

Prochaska, J. O. \& DiClemente, C. C. (1983). Stages and process of self-change of smoking: Toward an integrative model of change. Journal of Counsulting and Clinical Psychology, 51(3), 390-395. https://doi.org/10.1037//0022-006x.51.3.390

Silverman, D. (2008). Interpreting qualitative data (3. utg.). Thousand Oaks, New Dehli: Sage. Sletteland, N. (2014). Helekommunikasjon og digitale medier. Oslo: Gyldendal akademisk.

Stang, I. (2009). Being in the same boat: An empowerment intervention in breast cancer selfhelp groups (Doktorgradsavhandling, Fakultet for psykologi). Universitetet i Bergen, Bergen.

Statistisk sentralbyrå. (2019, 5. mars). Slik definerer SSB innvandrere. Hentet fra https://www.ssb.no/befolkning/artikler-og-publikasjoner/slik-definerer-ssb-innvandrere

Statistisk sentralbyrå.( 2016, 21. juni). Befolkningsframskrivinger, 2016-2100. Hentet fra https://www.ssb.no/befolkning/statistikker/folkfram/aar/2016-06-21

Stubbs, J., O`Reilly, L. M., Whybrow, S. \& Fuller, Z. (2014). Measuring the difference between actual and reported food intakes in the context of energy balance under laboratory conditions. British Journal of Nutrition, 111(11), 2032-2043. https://doi.org/110.1017/S00071145154

Säljö, R. (2001). Laring i praksis: Et sosiokulturelt perspektiv. Oslo: Cappelen. 
Thagaard, T. (2009). Systematikk og innlevelse: En innføring i kvalitativ metode (3.utg.). Bergen: Fagbokforlaget.

Tran, A. T., Diep, L. M., Cooper, J. G., Claudi, T., Straand, J., Birkeland, K., . . Jenum, A. K. (2010). Quality of care for patients with type 2 diabetes in general practice according to patients' ethnic background: a cross-sectional study from Oslo, Norway. BMC Health Services Research, 10, 1-9. https://doi.org/10.1186/1472-6963-10-145

Utdanningsdirektoratet. (u.å.). Fagfornyelsen. Hentet fra: https://www.udir.no/laring-ogtrivsel/lareplanverket/fagfornyelsen/

Vike, H og K. Eide (2009) Kulturanalyse, minoritetsperspektiv og psykososialt arbeid. I. Eide, M. Rugkåsa, N. Qureshi og H. Vike (Red.), Over profesjonelle barrierer - et minoritetsperspektiv i psyksosialt arbeid med barn og unge (s.13-35). Oslo: Gyldendal akademisk.

Wester, A., Wahlgren, L., Wedman, I. \& Ommundsen, Y. (2008). Å bli fysisk aktiv. I R. Bahr (Red.), Aktivitetshåndboken: Fysisk aktivitet i forebygging og behandling (s. 84-102). Oslo: Helsedirektoratet.

Wium, C., Gulseth, H. L., Eriksen, E. F., \& Birkeland, K. I. (2013). Characteristics of glucose metabolism in Nordic and South Asian subjects with type 2 diabetes. PLoS One, 8(12), 1-10. https://doi.org/10.1371/journal.pone.0083983 